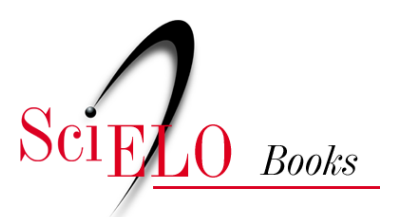

\title{
Conclusão \\ Até a última ponta...
}

\author{
Jorge Emanuel Luz de Souza
}

\section{SciELO Books / SciELO Livros / SciELO Libros}

SOUZA, J.E.L.S. Conclusão - Até a última ponta.... In: Sonhos da diamba, controles do cotidiano: uma história da criminalização da maconha no Brasil republicano [online]. Salvador: EDUFBA:

CETAD/UFBA, 2015, pp. 219-240. Drogas: clínica e cultura collection. ISBN: 978-85-232-2023-5. https://doi.org/10.7476/9788523220235.0007.

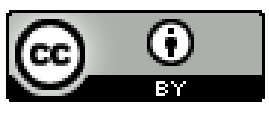

All the contents of this work, except where otherwise noted, is licensed under a Creative Commons Attribution 4.0 International license.

Todo o conteúdo deste trabalho, exceto quando houver ressalva, é publicado sob a licença Creative Commons Atribição $\underline{4.0}$. 


\section{CONCLUSÃO - ATÉ A ÚLTIMA PONTA...}

Quem estivesse em Salvador na véspera dos festejos cívicos da Independência da Bahia do ano de 1958, poderia se divertir ou se horrorizar, a depender da opinião que tivesse sobre o assunto, com uma matéria de $A$ Tarde cujo padeiro protagonista, um "maconheiro" um tanto eloquente, não escondia que era bem chegado em "apertar a massa":

'SOU VICIADO E NINGUÉM TEM NADA COM ISSO' - Sentindo ainda os efeitos de uma sôfrega tragada da 'erva maldita', o padeiro Abigael Pereira (solteiro, pardo, 24 anos) foi preso na tarde de ontem [...]. Levado ao xadrez mostrava-se calmo e garantia que nunca deixaria de fumá-la, pois achava aquilo uma 'delicia' [...].

- Não sou um criminoso - disse - nem tampouco um cachaceiro. [...] Os maconheiros deveriam ser livres. Não fazemos mal a ninguém. A maconha nos serve de alívio; conforta-nos e nos faz sonhar com coisas lindas. ${ }^{37}$ (MACONHEIRO, 1958, p. 6)

37 Tomei conhecimento deste ocorrido através do trabalho de Antônio José Costa Cardoso. O autor analisa a matéria abordando-a a partir da perspectiva da micro-história de Carlo Ginzburg, sugerindo semelhanças entre Mennochio e Abigael. Aqui, analiso o caso buscando demonstrar que os usuários eram um grupo extremamente heterogêneo e que nem todos se enquadravam no estereótipo de "maconheiro" de especialistas e autoridades do proibicionismo. 
O padeiro deixou "a bicicleta de entregar pão parada na porta" de uma garagem e decidiu entrar para fumar. Alguns instantes depois foi surpreendido pelos policiais, mas "não ofereceu resistência e entregou o pacote da maconha", que "havia comprado momentos antes de um tal de "Zezé"' por 50 cruzeiros. (MACONHEIRO, 1958, p. 6)

Abigael era natural do Rio de Janeiro, tinha estudado até o "terceiro ano primário" e começado a trabalhar cedo: "Os anos passaram. Tornei-me rapaz. O mundo era meu e abandonei minha casa". Com 17 anos conheceu a maconha e alguém lhe ensinou a "dar uma puxada"; "alguém" que ele diz não se lembrar e mesmo "se lembrasse, não o acusaria".

Quando fumava, Abigael imaginava "[...] estar sendo rodeado por um grupo das mais belas mulheres do mundo". Declarava solenemente: "Sou um viciado e adoro meu vício". (MACONHEIRO, 1958, p. 6)

Como se vê, o caso de Abigael destoa um pouco dos casos de prisão por porte ou consumo de maconha vistos aqui, nos quais a regra era negar a relação com a erva ou minimizar a encrenca alegando ser usuário de "primeira viagem". Ao contrário, o padeiro, quando levado à delegacia, "mostrava-se calmo", declarando que "nunca deixaria de fumá-la". Manifestando sua opinião sobre os usuários, afirmou que "os maconheiros deveriam ser livres", pois "não fazem mal a ninguém”, o que o faz opô-los ao "cachaceiro". Naquilo que pensava sobre a droga a considerava um "alivio", era um "conforto", o levava ao sonho "com coisas lindas" e "belas mulheres", as mais belas do mundo.

Os médicos e autoridades públicas devem tê-lo julgado louco, um "fumante inveterado", e visto nele os sintomas do "maconhismo crônico", um viciado tão dominado pelo vício que se mostrava incapaz de conseguir libertar-se dele e anunciava 
de antemão que nunca o abandonaria. Pior, que o adorava. Podem ter concluído, diante das suas considerações, que aquele homem era um ignorante, buscando na droga alento para as misérias da vida, assim como os especialistas do combate à maconha entendiam. As imagens que descrevia dos seus efeitos psicoativos, então, representariam um mundo de fantasia, uma "fuga da realidade", argumento ainda muito comum nos dias atuais para lidar com a questão.

Para esses agentes do proibicionismo, Abigael era sim um criminoso. E além de criminoso, um toxicômano, um doente. Porém, o leitor que nos acompanhou até aqui deve ter percebido que a singularidade do padeiro Abigael aponta para outra direção. Ao interromper a labuta diária para "dar uma puxada", algo que deve ter feito muitas outras vezes ao longo dos seus sete anos de usuário, ele nos mostra ter consciência que o hábito poderia conviver sem transtornos com a sua vida. Não sairia daquela garagem e atacaria as pessoas sem motivo ou roubaria a mercadoria que vendia, caso os pães não fossem seus. Pegaria a bicicleta que havia deixado na porta e continuaria com o seu trabalho.

O padeiro não reagiu à abordagem policial e no "xadrez" "mostrou-se calmo", quando soldados, delegado e jornalistas esperavam o oposto, um ataque de "loucura furiosa", tal como pregavam médicos e psiquiatras. O "show" dado por ele foi diferente do que a espetacular chamada do artigo policialesco dá a entender. Apesar de usar as expressões "vício" e "viciado", próprias do vocabulário proibicionista, demonstra que lhes atribuía significados diferentes, muito distantes das opiniões daqueles agentes: era trabalhador e não estava a provocar desordens, "não fazia mal a ninguém". Seu hábito era um assunto de direito individual e ele insistia em afirmar sua autonomia: "ninguém tem nada com isso". 
Contrariando as expectativas, Abigael concluía que mesmo sendo usuário de maconha não era um criminoso, pois não se via encaixado na imagem de "maconheiro" que tentavam lhe impor.

Esse caso instigante nos faz viajar por muitas das questões levantadas ao longo das páginas precedentes. Inicialmente, foi demonstrado como foi criado o proibicionismo brasileiro das drogas entre as décadas de 1930 e 1940, que agregou paulatinamente leis, instituições públicas, cientistas, polícia, justiça e imprensa num esforço comum de criminalização e repressão aos usos da maconha. Contudo, esse processo é iniciado pelo médico sergipano José Rodrigues Dória em 1915, quando viajou a Nova Iorque para apresentar num congresso científico "Os fumadores de maconha: efeitos e males do vício", texto que viria a ser o principal alicerce do discurso proibicionista no Brasil. Formado pela Faculdade de Medicina da Bahia, tornou-se professor de Medicina Legal e Toxicologia nessa instituição ainda no período imperial, seguindo também carreira política, os passos naturais da maioria dos médicos naqueles tempos.

Dória forneceu os principais argumentos da campanha repressiva antimaconha no Brasil. A partir do seu artigo, o uso psicoativo da planta seria considerado uma "toxicomania": um "vício imperioso, dominante e tirânico" que gerava loucura, incitava a prática de crimes e contaminava o "organismo social" hereditariamente. Os usuários, além de criaturas impotentes diante do entorpecente, estariam apenas nas "camadas mais baixas da sociedade", onde se nota o delineamento de um perfil de classe para o fenômeno. E não sendo a planta nativa do país, tem sua origem encontrada na África: foi trazida pelos negros, considerados "selvagens" e "inferiores", para vingarem-se dos brancos, "mais adiantados em civilização", por terem sido escravizados por estes. 
Esse discurso foi construído, como visto, no momento em que as elites políticas e econômicas da Bahia e do Brasil preocupavam-se com as classes subalternas, agora não mais sujeitas, como antes, aos controles da ordem senhorial. As proposições de Dória tomaram feições eugênicas e racistas, pois buscavam instituir, através da repressão à maconha, mecanismos de exclusão de grupos sociais específicos (negros, mulatos e pardos pobres) por ele associados à prática que condenava, o que contribuía para a manutenção das antigas estruturas sociais.

Porém, os apelos médicos em relação aos "efeitos e males do vício" da maconha só foram ouvidos pelas autoridades públicas algum tempo depois. Entre 1915 e 1932, ano em que foi criminalizada, o Estado se limitou a ratificar uma convenção internacional e editar uma lei sobre a questão das drogas em 1921, mas nenhuma das normas se ocupava da maconha. No seu lugar, o foco incidiu sobre o ópio, a morfina e a cocaína, drogas consumidas nos circuitos sociais das elites. Segue-se um lapso de quase duas décadas, evidenciando que medicina e Estado ainda não se entendiam muito bem nesse terreno e possuíam preocupações diferentes.

A maconha entraria na cena proibicionista em terras brasileiras na década de 1930 como parte de um largo raio de ação do governo Vargas em relação ao "problema dos entorpecentes" que, por sua vez, integravam os projetos mais amplos daquele regime, agora voltados de formas específicas para a coletividade. Foi nesse contexto que se buscou uma atualização permanente no assunto através da participação do país nas conferências internacionais sobre drogas promovidas pela Liga das Nações, a exemplo da realizada em 1936, da incorporação de suas convenções à legislação nacional, do intercâmbio com diversos países, da assinatura de acordos de cooperação para a 
repressão das drogas com países vizinhos, da ampliação e enrijecimento das leis brasileiras e da criação de órgãos especializados para coordenar esse trabalho, como a CNFE e as Cefe.

Isso se deu num contexto internacional de avanço da condenação e repressão a todo uso não científico dos psicoativos, coincidentemente o momento de maior produção e descoberta de novas drogas. Nesse plano, os papéis decisivos foram assumidos pela Liga das Nações, organismo criado em 1919 nas ressonâncias da Conferência de Paz de Paris após o término da I Guerra Mundial para arbitrar conflitos internacionais, e pelos Estados Unidos, a grande potência mundial já naquele período. Foram os interlocutores principais do Brasil no assunto das drogas e muito influenciaram o modelo de gestão assumido pelo Estado nacional na questão. Estes foram interlocutores também com outros países da América do Sul, que ao longo da década de 1930 também adotavam o modelo proibicionista, tais como a Venezuela, a Argentina e o Chile.

Chegou-se à conclusão, analisando diversas evidências, que o proibicionismo brasileiro das drogas, sobretudo em relação à maconha, esteve diretamente ligado a esse movimento global. Entretanto, ao contrário do que poderia levar a crer, esse processo na década de 1930 não foi mera transposição de modelos externos ou uma admissão automática das diretrizes vindas de fora, mas sim uma adaptação desses ao contexto interno.

Absorviam-se as questões do plano internacional, filtravam-se os ditames de acordo com realidades concretas e avaliavam-se as possibilidades para melhor adequar esses mecanismos aos interesses dos grupos no poder, transformados em "interesses nacionais". Exemplo disso é o fato de que a maconha está ausente da lista proibitiva da Convenção Internacional do Ópio de 1931, confeccionada pela Liga das Nações numa 
conferência realizada em Genebra, com participação do Brasil, e figura pela primeira vez entre as substâncias proibidas por aqui um ano depois, por meio do Decreto n. 20.930 de 1932.

Considerou-se, então, a década de 1930 "a década das proibições" ou "década do proibicionismo", em matéria de drogas, no Brasil, pelo caráter organizador que apresentou.

Mas se o ideário de combate à maconha passa a ser inaugurado na década de 1910 e o aparato repressivo foi constituído nacionalmente na de 1930, na Bahia ele começa a funcionar efetivamente nos anos 1940 com a formação da Comissão Estadual de Fiscalização de Entorpecentes. Além disso, intensificaram-se os trabalhos da CNFE, montada na década anterior, com a promoção de reuniões e viagens de inspeção por todo o Brasil, bem como a divulgação de diversos trabalhos dos mais variados campos da ciência sobre a maconha.

A Cefe baiana, que agregava em seus quadros médicos, juristas e autoridades policiais, mereceu os aplausos do doutor Roberval Cordeiro de Farias, presidente da CNFE, quando de suas duas "viagens de inspeção" ao estado em 1941 e 1943, e do doutor Eleyson Cardoso, representante da CNFE no Convênio Interestadual da Maconha. Esse evento, realizado em Salvador no ano de 1946, reuniu representantes de quatro estados nordestinos com a intenção de empreenderem uma ação conjunta de repressão e controle na matéria. Acabou também produzindo dezenove "conclusões", dentre as quais a que sugere a "matrícula de cultos afro-brasileiros" nas delegacias de costumes estaduais, conectando-se a um dos principais consensos daqueles agentes: havia entre os usuários de maconha "predominância de pretos e mulatos". Esta proposição, além de fazer ecoar aquele discurso médico fundador do "problema da maconha", abria a possibilidade da intervenção violenta do Estado sobre a religião na qual esses sujeitos eram maioria. 
E como a complexidade é a regra dos empreendimentos humanos, isso tudo foi menos linear do que aparenta. Se médicos e governo levaram quase vinte anos pra se entenderem quanto à maconha, esses e outros especialistas ainda continuariam reclamando, durante os anos 1930, da falta de medidas estatais mais fortes para combater a expansão do seu consumo. A imprensa, por sua vez, ora ovacionava ora criticava todo mundo, sobretudo os agentes militares, que deveriam combater o uso e o comércio da "erva maldita", mas diversas vezes faziam vistas grossas para a prática ou mesmo se envolviam nela. Até mesmo médicos, como o prefeito de Piaçabuçu em Alagoas, Antonio Machado Lobo, reclamavam que a corporação era a principal beneficiada pelo mercado ilegal da maconha: "tem dado é muito dinheiro para a polícia, essa é a verdade". (ARAÚJO, 1979, p. 259)

A legislação antidrogas brasileira não nasceu pronta e os órgãos de repressão estavam longe da perfeição que idealizavam, o que evidencia haver uma defasagem entre a legislação e a prática criminalizadora. A própria Liga das Nações, longe de ser um fórum harmônico congregando os países preocupados com a saúde pública mundial, se mostrava, nas palavras do delegado brasileiro presente na Conferência de Genebra em 1936, "dividida em pontos de vista diametralmente opostos", cada um desses ligados a determinados interesses político-econômicos. A criação de um comitê nacional para organizar e liderar o combate às drogas no Brasil foi uma ideia manifestada pela primeira vez em 1916, mas só conseguiu ser viabilizada vinte anos depois. Mesmo após a sua formação e funcionamento, as comissões estaduais ainda buscavam aperfeiçoar os mecanismos de atuação, atrapalhados, segundo seus próprios membros, pela burocracia e pelo centralismo do governo federal. 
Outro ponto a ser destacado é a ambígua relação que Estado e medicina oficial mantinham com a Cannabis nos idos da primeira metade do século XX. Pode-se descobrir que o Instituto Agronômico de Campinas realizou "várias tentativas de exploração comercial" de uma variedade de Cannabis batizada como Hibiscus cannabinus ou ainda cânhamo brasileiro, do qual obteve "resultados muito satisfatórios" com "fibras de apreciável valor econômico". Essa história só nos foi revelada porque, em 1932, o corpo diplomático brasileiro em Cuba solicitou ao Itamaraty informações e um pouco de sementes da referida planta, a pedido do general Molinet, Secretário de Agricultura daquele país. E o governo enviou, no ano seguinte chegam 200 gramas de sementes de "cânhamo brasileiro" em Cuba. Contraditório para um Estado que promovia intensa campanha para exterminar a planta por aqui?

Avançando alguns anos se percebeu que se desde 1932 já se encontrava no rol das substâncias proibidas por lei, sendo confirmada essa criminalização em 1938 com o Decreto-Lei n. 891, a maconha também estava na "Tabela D" das "Instruções" para a execução desse decreto, que estabelecia a "Relação dos entorpecentes de existência obrigatória nas farmácias" e aí estavam três de suas preparações. Essas eram importadas da Alemanha e durante o segundo trimestre daquele $1938 \mathrm{em}$ quantidade de 42 quilogramas, juntamente com 10 quilogramas da "maldita". Ou seja, toda farmácia era obrigada a guardar, manipular e vender maconha, ainda que transformada, contribuindo assim para a perpetuação da espécie.

Com isso, ficou claro que o mesmo Estado e a mesma ciência que a demonizava e estigmatizava seus usuários, criou uma variedade brasileira da planta, determinava a sua "existência obrigatória" em estabelecimentos farmacêuticos e a adquiria no exterior como qualquer mercadoria importada. Ou 
seja, a maconha se tornava um "mal", um "flagelo social" a depender da ocasião, a depender da forma de uso e de quem o fizesse. Como foi possivel constatar, através do caso de Raimundo e Pedro, os consertadores de caixas do porto do Rio de Janeiro, nos fins de 1941, eram pessoas como eles, pobres e sem as "devidas autorizações", que ativavam esse "mal" seletivo para as autoridades. Outras questões e interesses poderiam resultar em outras posturas das autoridades públicas e médicas em relação à planta e seus usuários.

Partindo desse pressuposto, foram acompanhados de perto os jornais da capital baiana ao longo da década de 1950 para conhecer um pouco mais do mundo das classes trabalhadoras que a habitavam e, assim, compreender por que eram insistentemente apontadas como as únicas consumidoras de maconha no Brasil. Na documentação produzida pela CNFE em viagem à Bahia para analisar a extensão do "problema da maconha" estão listadas as profissões de dezenas de usuários fichados na polícia: eram colchoeiros, jornaleiros, barbeiros, vendedores ambulantes, engraxates, funileiros, portuários, mecânicos, carpinteiros, pedreiros, alfaiates e açougueiros, entre outros. Ocupações das classes subalternas da cidade, que também figuravam nos diversos conflitos sociais do período.

O discurso proibicionista no Brasil consolidou um estereótipo do "maconheiro", mantido sem alterações até pelo menos meados da década de 1960 e seguido à risca pelas autoridades policiais e jurídicas, no qual o estigma se tornou um amplo guarda-chuva criminológico capaz de abrigar uma variedade imensa de sujeitos sociais. O intuito, nesse aspecto, era reduzir a heterogeneidade de experiências dos usuários com a droga a um denominador comum, seguindo os preceitos traçados pela medicina social de então: "seus viciados pertencem à última e mais baixa escala social". Foi necessário contextualizar essa 
afirmação para compreender os conflitos de classe que encerrava e por isso enveredou-se pelo cotidiano dos subalternos na Salvador dos anos 1950 do século XX.

Nesse quadro estavam os trabalhadores do comércio popular. Através de experiências como a de Severino Correia, foi demonstrado que vendedores ambulantes, camelôs e feirantes viviam sob constante vigilância policial e repressão da fiscalização municipal. Em parte porque, na visão da maioria das elites e da imprensa, representavam uma afronta aos "foros de civilização" da cidade, assim como os mercados e feiras livres que a pontilhavam. Se andavam em atrito com a municipalidade, em sua ânsia disciplinadora da categoria, também viviam em guerra com a Federação Comercial, poderoso inimigo que se sentia prejudicado pelo comércio popular das ruas. As dificuldades financeiras cotidianas enfrentadas por esse grupo dos trabalhadores urbanos serviram como fundamento da suspeita que lhes imprimiam seus opositores. Aos olhos da polícia e da imprensa foram todos transformados em potenciais traficantes de maconha, o que justificava a ação violenta sobre eles.

Não estavam sós, no entanto. Nessa peleja foram acompanhados por trabalhadores portuários, canoeiros, pescadores e marujos. Trabalhassem sobre água doce ou salgada, nas vagas do Atlântico ou nas correntes do São Francisco, foram responsabilizados pela propagação do hábito do consumo de maconha no Brasil. Na Bahia, inclusive, não só os nacionais a fumavam. Os norte-americanos, oriundos da principal nação proibicionista, também o faziam, deixando as autoridades enfurecidas com tamanha contradição.

O porto de Salvador, palco de diversas intervenções modernizantes na primeira metade do século passado, também vivenciou intensos conflitos sociais, tendo ativa participação desses trabalhadores em manifestações contra a carestia de 
vida e nas muitas greves que pipocaram no período. O discurso proibicionista desenhou um perfil para os portuários, que aliava as famosas e estereotipadas características de violentos, rixentos e criminosos com a ideia da "loucura canábica", criando a necessidade da vigilância. Entretanto, para elucidar a sua irredutibilidade a esse perfil foi analisado o caso do "detento 392" da Penitenciária Estadual, no qual o médico João Mendonça buscava comprovar os efeitos homicidas da droga, mas também demonstrou que esses sujeitos eram mais heterogêneos do que afirmava.

As autoridades policiais estavam igualmente atentas aos artistas, principalmente estrangeiros, quando o assunto era a maconha. Os músicos cubanos que formavam o conjunto "Mambo Dandies" e acompanhavam a cantora Lia Ray sentiram na pele essa atenção em 1951. Após arrancar aplausos do público na capital, foram presos de madrugada no Tabarís e conduzidos ao Palace Hotel, onde se hospedavam, para terem seus pertences revistados, onde foi encontrada certa quantidade da erva. Como se não bastasse a prisão e a privacidade violada, acabaram ainda sendo submetidos a "testes psicológicos" para comprovar a sua sanidade mental. Ou seja, bastou a suspeita da presença da droga para mobilizar todo um aparato espetacular de constrangimento contra aqueles artistas, por sinal, negros e pardos. É, parece que não é de hoje que a droga serve de motivo para intervenções violentas na vida dos indivíduos.

E pra não dizer que não se falou das flores, ou melhor, da "fina flor da sociedade", foram encontradas algumas evidências que contrariavam o argumento classista dos especialistas do combate à maconha. Ainda que preferissem "vícios elegantes", parisienses e cosmopolitas como a cocaina - merecedora, inclusive, das homenagens do distinto sambista Sinhô -, assim 
como preferiam o burburinho dos cafés e cabarés das prostitutas de luxo, as "categorias sociais mais elevadas" e seus "bons moços" não deixaram de conhecê-la.

Teria andado na corte joanina no Brasil, "subindo os degraus da realeza" através de suas propriedades venenosas, segundo o escritor Assis Cintra. Contato não desprovido de possibilidades, haja vista que a planta era conhecida e explorada há séculos pelos portugueses, tendo a Coroa implantado uma feitoria na colônia para produzir e exportar a sua fibra têxtil.

No século XIX, o uso de medicamentos à base da Cannabis era receitado por médicos aos seus pacientes grã-finos, prática retratada no conto "Haxixe" de Olavo Bilac, bem como, sua presença era comum em manuais de medicina, a exemplo do "Formulário e Guia médico" de Pedro Napoleão Chernoviz. Além do mais, os ricos poderiam adquirir as "Cigarrilhas Grimault" ou "cigarros índios", feitos de Cannabis, bastava abrir um jornal, como aquele de 1905 que as propagandeava contra asma, catarros e insônia. O que se percebe, mais uma vez, é que nem sempre maconha e medicina estiveram em lados opostos nas trincheiras.

Mais alguns casos, como os dos "bons moços paulistas", brancos, presos em 1958 por uso de maconha, noticiado por um jornal de Itabuna, no interior da Bahia, que também apontava esse consumo entre "pessoas bem estabelecidas" naquela cidade; e o relato do prefeito de Piaçabuçu, Alagoas, de que "rapazes se reuniam para fumar maconha" em Salvador à época em que era estudante da Faculdade de Medicina, trazem ainda mais elementos. Pelo visto, seus "afeiçoados" não foram sempre os da "mais baixa escala social".

Voltando para o mundo dos subalternos, foi visto que a maconha era tida como inseparável mesmo da vida da "malandragem". Eram os "capitães de areia" na Bahia, "maloqueiros" 
em Pernambuco ou "ratos cinzentos" em Sergipe. Dominavam as páginas policiais dos periódicos, apresentando ainda outras designações: "gatunos", "lanceiros", "meliantes", "mundanas" e "decaídas". Em coletivo tornavam-se, pelas palavras da imprensa, a "claque", a "escória" que coloria a "aquarela do crime" de Salvador, protagonizava "cenas de filme de James Dean" e transformava diversos pontos da cidade em "quartel general da ociosidade". Como solução, recomendava-se uma verdadeira "limpeza social", tendo no trabalho um poderoso regenerador.

A capital baiana se transformava, crescia em extensão e população. Com isso, crescem, paralelamente, as preocupações do poder público com o controle do espaço urbano e da vida social em diversos sentidos. Foi nesse contexto que se deu a atualização e o aperfeiçoamento de saberes e instrumentos de gerência dos indivíduos e dos espaços, com destaque para o urbanismo e a criminologia. A cidade estava dividida em três circunscrições policiais que possuíam as suas respectivas delegacias, vigiando doze distritos, no que eram ajudadas por outras três.

Mesmo reconhecendo que existiam problemas policiais em toda a cidade, a vigilância e a repressão tinham como foco principal as regiões de grande concentração popular, zonas de circulação das classes subalternas: onde trabalhavam, se divertiam e estabeleciam seus contatos e redes de sociabilidade. Por isso a atenção dada à presença da maconha na Rua da Ajuda - a "Esquina do pecado" -, na Rua do Tesouro, onde se fumava na "escada de Cimara", na Baixa dos Sapateiros, coração do comércio popular da capital e nas suas ligações com a cidade alta, a Ladeira da Ordem Terceira de São Francisco e a de São Miguel. Esses foram os cenários de alguns casos acompanhados aqui, como o do "célebre Bandeira", o do grupo liderado por "Zé macaco" e o do tatuado "Hermes Pinta Preta". 
Autoridades públicas e cientistas imbuídos da repressão à maconha e seus usuários das classes subalternas falavam línguas diferentes, atribuiam diferentes sentidos ao seu consumo. Estes, como viviam experiências diferentes, compartilhavam significados próprios em relação à prática. O "caráter gregário" do consumo de maconha, ou seja, seu uso coletivo, sempre chamou a atenção dos especialistas no assunto, chegando mesmo alguns a afirmarem que havia entre os usuários "a convicção de que precisa ser usada em sociedade”. Essa característica assombrava ainda mais os agentes do proibicionismo.

Porém, à medida que eram ampliados e aprofundados os estudos sobre o uso psicoativo da maconha, as próprias observações e dados apresentados por médicos e autoridades entre as décadas de 1930 e 1950, evidenciam sua complexidade. Ao lado do esforço de montar um perfil criminológico do "maconheiro", passaram também a se interessar cada vez mais pelos contextos culturais nos quais apontavam a sua presença.

Realizavam experiências de laboratório, acompanhavam sessões de uso coletivo e até mesmo auto-observações foram feitas pelos especialistas que acabaram expondo pequenas dúvidas e discordâncias entre eles. Essas evidências relativizavam a homogeneidade do modelo de "maconheiro" criminoso e doente que defendiam. E ainda que não diminuísse a crença compartilhada por eles da necessidade de se erradicar a maconha da sociedade brasileira, expunha os limites do discurso proibicionista.

Passava-se, por exemplo, a afirmar que os efeitos variavam conforme a constituição biológica individual e dependiam do estado psicológico do sujeito; admitia-se que a criminalidade não era resultante apenas de características naturais endógenas ao indivíduo, no que reside parte do interesse pelas relações e práticas envolvidas no seu uso; discutiram também 
a natureza "habituogênica" da maconha, ou seja, se levaria inevitavelmente a um "vício crônico", visto que percebiam uma inegável variação nas formas dos sujeitos se relacionarem com a droga. ${ }^{38}$

Essas observações, que por vezes se assemelham a verdadeiras investigações etnográficas e etnolinguísticas sobre as populações brasileiras, foram publicadas em revistas de medicina, psiquiatria, criminologia, botânica e agricultura ou mesmo em livros sobre a cultura popular nacional, assim como não deixou de permear páginas da literatura. A maioria delas acabou reunida, em 1951, e reeditada em 1958, numa obra de peso singular para a construção do problema da maconha no Brasil: Maconha - Coletânea de trabalhos brasileiros. Fazendo uma leitura a contrapelo dessas fontes, foi possivel conhecer os significados atribuídos pelos usuários à prática do uso coletivo de maconha e se deparar com uma multiplicidade de formas desse uso, ambos reconfigurados a partir dos elementos de cada contexto social.

As técnicas de consumo são um exemplo dessa variedade. Quando fumada, a forma mais usual de alcançar os seus efeitos psicoativos, poderia ser consumida em cigarros de diferentes tamanhos, cada um com seus nomes conferidos pelos usuários ou em cachimbos, em geral, denominados de "maricas". O cachimbo, produzido com diversas matérias-primas, porém sendo a mais utilizada a cabaça, foi considerado algo típico do uso coletivo de maconha nos sertões da região Nor-

38 O dr. Heitor Peres, por exemplo, faz a seguinte ponderação no seu estudo na década de 1930: "Quaisquer que sejam as manifestações clínicas da intoxicação pela diamba, seja qual for o estado mental do diambista, o que se observa, confirmado pela Comissão Estadunidense que bem estudou a marihuana [no Panamá, quando da construção e domínio imperialista do Canal], e pelos pesquisadores que se entregaram ao estudo da maconha ou mesmo do haschich, é forçoso concluir, que a intoxicação diâmbica, ou similar, não traz crise de abstinência ou, mais claramente, não provoca falta". (PERES, 1958, p. 71) 
deste. Esse objeto não era apenas uma utilidade, mas poderia apresentar muito da identidade dos usuários, pois, não raro, era adornado, estetizado, o que também lhe atribuía um caráter "exótico", como considerou o Diário de Notícias em 1958 na ocasião da inauguração do Museu Antropológico do Instituto Médico Legal da Bahia.

A "maricas" foi considerada pela literatura proibicionista uma técnica tributária do negro africano ou uma "imitação tosca" do cachimbo oriental chamado narguilé. Seguindo essas indicações, foram estabelecidas as conexões dessa técnica no Brasil com outras partes do mundo, sobretudo com a África. A partir de relatos históricos, como o dos oficiais portugueses Roberto Ivens e Hermenegildo Capelo no final do século XIX, foram identificados traços em comum entre as práticas de um lado e do outro do Atlântico, a exemplo das matérias-primas utilizadas para confeccionar o cachimbo e os ritos presentes nas ocasiões de uso coletivo.

Assim, foi delineado parte do percurso de difusão da Cannabis pelo mundo, partindo do Oriente, na Índia, até atingir os continentes africano e europeu. Transportada na bagagem de seculares rotas comerciais, teve seu uso incorporado a diversas culturas africanas, que transformaram não apenas as expressões banghou bangi, usadas na Índia, e haschisch, empregada pelos árabes, mas também as próprias formas de consumo e os sentidos que elas continham. Foi visto, então, que expressões usadas para se referir à maconha no Brasil ao longo da primeira metade do século XX, como liamba, riamba e diamba, tinham origem nas linguas "bantu" faladas por diversos povos que foram trazidos para cá como escravos.

Mas as semelhanças não paravam nas nomenclaturas. O cachimbo chamado de "maricas" e utilizado para fumar maconha atravessou distâncias e tempos mantendo um princípio 
que possuía duas características importantes para o uso coletivo: um recipiente para pôr líquido, em geral, água. Por um lado, servia para resfriar a fumaça antes de ser inalada, por outro, produzia um burburinho com a sua passagem pelo liquido. No primeiro caso, se mostra um eficiente mecanismo de redução de danos, que não deixou de ser percebido pelos especialistas do proibicionismo, para quem os usuários empregavam "vários recursos empíricos" para "prevenir surpresas". No segundo, agia como um estimulante muito apreciado pelos usuários para alcançar os efeitos desejados.

Com isso, aqueles cientistas não estavam equivocados ao estabelecer tais conexões atlânticas dos usos de maconha no Brasil, porém estavam alicerçados na ideologia racista que buscava na sua origem africana a fonte de todos os males. Não por acaso também foi chamada pela imprensa carioca de "veneno africano". (VENENO, 1930, p. 1)

A "maricas" estava comumente inserida num contexto de uso um tanto ritualizado, que ficou conhecido na literatura proibicionista ou folclórica como "clube de diambistas". Descrito como característico das zonas rurais das regiões Norte e Nordeste, assim como a "maricas", foi alvo do interesse do olhar científico e da preocupação de médicos, psiquiatras e autoridades públicas. Estes viam nos "clubes" o perigo de intensificar os efeitos da maconha, levando gradualmente os indivíduos à prática criminosa e à depravação moral sob os "chistes e galhofas" do coletivo.

Como as reações e os efeitos observados nos "clubes de diambistas" contrariavam as suas expectativas, buscaram enquadrar os usuários em outra categoria: o "maconhismo crônico". Esse seria favorecido pelas características ecológicas do sertão brasileiro, com suas misérias e flagelos que empurrariam os seus ignorantes habitantes para as "ideologias abstru- 
sas" e para a busca de qualquer alento para seu sofrimento. Os especialistas do proibicionismo brasileiro das drogas partilhavam uma concepção negativa do sertão e do sertanejo, identificando neste território e nestes sujeitos a parte atrasada do país, a face degenerada da identidade nacional que precisava ser higienizada e modernizada.

A diversidade de componentes da questão, bem como sua longevidade histórica, se expunham os limites do proibicionismo também reafirmavam nas autoridades a proibição e a profilaxia da maconha no Brasil, como atestou José Lucena, assistente do Serviço de Higiene Mental de Pernambuco, para quem se tratava de "[...] uma das mais divulgadas, antigas e temíveis intoxicações euforísticas”. (LUCENA, 1958, p. 208) As variações nos efeitos relatados, a variedade de práticas ligadas à planta e a diversidade dos comportamentos observados serviam como prova da "aculturação do diambismo" no país, do quanto o vício já havia se fundido aos "nossos costumes e fatores étnicos". Assim procedeu o médico Garcia Moreno ao reduzir as trovas e loas dos diambistas a "uma inspiração de base alucinatória”. (MORENO, 1958, p. 158)

A prática de proferir versos nas sessões de uso coletivo de maconha, chamadas pela literatura proibicionista de "trovas", "poesia" ou "loas da maconha", foi uma especificidade desse consumo no Brasil. Esses versos, cuja prática se assemelha a diversas outras da cultura popular brasileira, tais como o jongo, o repente e a embolada, poderiam ser em tom de desafio ou não, apresentando-se, em geral, em quadras e seguidos de coros dos demais presentes, entrecortados por baforadas na "maricas".

Eram enunciações cheias de recursos estilísticos que abordavam diversas questões: exaltação ou discussão das características da maconha, assuntos do cotidiano da comuni- 
dade, a vida política, estratégias de manutenção do hábito em diferentes contextos e mecanismos de regulação do consumo. Os usuários "trovadores" demonstravam conhecimento dos códigos do grupo, dando seguimento ao assunto e propondo um novo ponto da questão, que deveria ser continuada por outro. Não sem razão as trovas foram consideradas, pela mesma literatura proibicionista, "uma pequena enciclopédia popular".

$\mathrm{O}$ que essas autoridades, que tomaram para si a missão de livrar uma sociedade inteira dos males terriveis do que consideravam um "mal", já percebiam era a existência de uma cultura especifica, inserida em diversos contextos históricos, com lógicas e códigos peculiares, com canais de informação específicos e dotados de mecanismos próprios de regulação e controle de suas práticas. O uso coletivo possibilitava um consumo seguro da droga, definido a partir das diversas experiências individuais, possibilitando a coexistência do hábito com a vida cotidiana dos usuários. Desenvolvia e punha em circulação controles sociais informais, compartilhando conhecimentos para a sua manutenção num momento de proibição.

Disso sabiam os usuários e as autoridades públicas, como prova a ficha de inquérito confeccionada em 1943 pela Cefe baiana que buscava saber se o usuário preso conhecia "provérbios, versos, anedotas e modinhas sobre a maconha". Disso sabiam também os médicos e demais especialistas que construíram as bases do proibicionismo da maconha no Brasil, pois reconheceram que os seus usuários "fumam a planta e dela sabem mil coisas".

Tomando as mesmas evidências e partindo de questões semelhantes, chega-se a outras conclusões. Como eles passavam a constatar cada vez mais, a planta Cannabis sativa possuía raízes profundas e bastante arraigadas na história da humanidade. Convivia com chineses, indianos, persas, gregos, 
citas, árabes, sírios, egípcios e outros povos africanos, europeus e americanos, alguns por séculos, outros desde milênios. Além de fumada era ingerida como alimento e bebida ou adicionada a estes em diversas ocasiões, fossem em palácios de monarcas, casas de barro do sertão, em meio a barracas de feira ou no interior de lares na cidade. De tempos distantes se sabia que dela eram extraídas curas para diversos males, assim como venenos. Ocupou páginas dos escritos de literatos, filósofos, historiadores e botânicos, aos quais não passou despercebida sua presença desde a antiguidade. Era a bebida preferida de deuses, alcançando status divino e considerada planta de poder mágico, veículo de acesso a outros estados de consciência em diversas culturas. ${ }^{39}$ Em suma, reconhecia-se que o fenômeno era multifacetado, pluriclassista e polissêmico.

A história da humanidade não pode ser apartada da história da produção e do consumo de substâncias psicoativas, essas são "parte da existência do homem" em diversas dimensões, sendo um erro e uma ilusão querer exterminá-las da sociedade. Décadas de repressão, que mistura uma confusão de fragmentos de discursos heterogêneos - médico-biológico, jurídico, moral, etc. - e seleciona arbitrariamente características e situações específicas (BARATTA, 1992), não conseguiram mais do que multiplicar os dividendos de um cruento mercado ilegal, que acaba incrementando ainda mais o sistema financeiro capitalista, atentar contra a saúde pública e superlotar as carceragens, sobretudo, de pobres.

39 Foi amplamente mencionada nessa literatura especializada a existência de referências milenares ao uso da Cannabis e seus derivados em poemas épicos e textos religiosos da Índia, Pérsia, China, Grécia, etc. Eleyson Cardoso, membro da CNFE, aponta, na década de 1940, Garcia da Orta, Heródoto, Galeno, Dioscórides, Paulo Aeginata, Homero, Marco Pólo, Gautier, Baudelaire e Alexandre Dumas, entre outros, como nomes de alguns dos que notaram a sua existência e uso nas sociedades ao longo da história. (CARDOSO, 1958b; CARNEIRO, 2002a) 
Sonhos da diamba

A espetacularização midiática das intervenções repressivas, como visto, comum desde a década de 1950, evidencia que esse tratamento proibicionista sempre foi tão ou mais simbólico que instrumental, pois não diminuiu as infrações que se propôs a extinguir. Dessa forma, evidenciou-se um constante sacrificio de bodes expiatórios para representar e confirmar a validade de uma norma autoritária e reducionista. O que se buscou ao longo dessa jornada foi reafirmar a autodeterminação de diversos saberes coletivos capazes de nos legar "[...] uma percepção realista, uma solução racional e justa dos problemas e conflitos" nesse campo. (BARATTA, 1992, p. 49) Sem homogeneizar como crime nem nivelar como doença, a autonomia individual na administração dos estados de consciência diz respeito "[...] ao direito imprescindivel do homem de definir ele próprio o seu caminho, de modo independente e sem tutelas". (SCHEERER, 1992, p. 68) 